\title{
ДЕКРИМИНАЛИЗАЦИЯ ДЕЯНИЯ КАК ОБСТОЯТЕЛЬСТВО, ИСКЛЮЧАЮЩЕЕ УГОЛОВНУЮ ОТВЕТСТВЕННОСТЬ
}

\begin{abstract}
Дорогин Д.А.
Аннотация: В статье затрагиваются некоторые спорные вопросы декриминализации деяния с точки зрения её отнесения к обстоятельствам, исключаюшим уголовную ответственность. Автором рассматриваются различные аспекты проблемы, приводятся имеющиеся в доктрине точки зрения $и$ формулируется собственная позищия. В частности уголовно-процессуальный закон не делает различий между отсутствием состава преступления как таковым и отсутствием состава преступления 8 связи с декриминализаџией деяния, причём ни с точки зрения оснований прекращения уголовного дела или уголовного преследования, ни с точки зрения возникновения права на реабилитацию. Метод или методология исследования: Для достижения цели и решения задач, стоящих перед исследованием были применены общенаучные и частно-научные методы, а именно: анализа и структурно-логический метод. Вывод: декриминализачия деяния должна рассматриваться как обстоятельство, исключающее уголовную ответственность. В содеянном одновременно отсутствуют состав преступления, а также такие признаки преступления, как противоправность и наказуемость. Представляется, что сегодня для признания декриминализачии деяния обстоятельством, исключающим уголовную ответственность, есть и теоретические, и материально-правовые, и прочессуально-правовые основания. Аналогично следует подходить к определению правовой природы отсутствия уголовного закона.
\end{abstract}

Ключевые слова: Декриминализация, деяние, обстоятельство, исключение, уголовная ответственность, доктрина, преступление, in abstracto, порицание, реабилитация.

В ч. 1 ст. 10 УК РФ закреплено, казалось бы, очевидное положение, в соответствии с которым уголовный закон, inter alia[1] , устраняющий преступность деяния, имеет обратную силу, то есть распространяется на лиц, совершивших соответствующие деяния до вступления такого закона в силу. В самом деле, если преступность и наказуемость деяния устраняются уголовным законом, то лицо не может подлежать ответственности за его совершение, - это представляется очевидным и не подвергается сомнению. Однако проблема правовой природы декриминализации деяния в аспекте её отнесения к числу обстоятельств, исключающих уголовную ответственность, порождает дискуссии.
В учебной литературе обычно отсутствует указание на сущность декриминализации деяния; авторы ограничиваются общим тезисом о том, что за деяние, признававшееся ранее преступным, устраняется уголовная ответственность[2] .

В решении этого вопроса следует исходить из того, что́ нового появляется или исчезает в норме с изменением уголовного закона в случае устранения преступности и наказуемости деяния. Безусловно, логично предположить, что декриминализация устраняет противоправность деяния, считавшегося ранее преступным[3] . Однако вместе с тем, следует обратить внимание ещё на одно обстоятельство.

Если в качестве примера взять in abstracto[4] два идентичных деяния, одно из которых было 
совершено до утраты уголовным законом силы, а другое - после этого, нетрудно прийти к выводу, что, хотя все их признаки совпадают, в первом случае уголовная ответственность будет наступать, а во втором она уже исключается. Отсюда можно заключить, что второе деяние не содержит состава преступления. В обоснование сказанного могут быть приведены два основных аргумента.

Во-первых, в соответствии со ст. 8 УК РФ основанием уголовной ответственности признаётся состав преступления. Поэтому в случае изменения уголовного закона таковая исключается в связи с отсутствием своего основания. Во-вторых, посягательство, совершённое после изменений уголовного закона, должно рассматриваться не изолированно, но во взаимосвязи с другими преступлениями, от которых данное деяние следует отграничивать. И если признаками ни одного из преступлений, предусмотренных другими статьями, содеянное не обладает, необходимо констатировать отсутствие состава преступления.

Поэтому не представляется возможным согласиться с позицией Г.А. Есакова, который, сравнивая декриминализацию деяния с другими факторами, в частности, с отсутствием вины, пришёл к выводу, что ненаступление уголовной ответственности в обеих этих ситуациях «очевидно < .. > связаны исключительно внешне». Из этого он заключает, что «внешнее уголовно-правовое следствие не должно маскировать различную в сущности юридическую природу»[5] . В данном случае речь идёт не о чём-то внешнем, но, напротив, о содержательной стороне проблемы. При декриминализации деяния уголовная ответственность лица исключается в силу одновременного отсутствия в содеянном признаков состава преступления, а также признаков преступления (прежде всего и во всяком случае - противоправности и наказуемости).

Противники признания декриминализации деяния обстоятельством, исключающим уголовную ответственность, могли бы вести речь ещё и о том, что преступность и наказуемость деяния устраняются в т.ч. и на стадии исполнения приговора, когда лицо уже признано виновным в совершении преступления и отбывает назначенное ему наказание. Соображения по поводу этого аспекта проблемы приводит А.П. Фильченко: если уголовная ответственность уже начала реализовываться к моменту декриминализации деяния, она лишается своего основания. Однако при этом «новый уголовный закон обращён к преступлению как наличному состоянию, а не к моменту его совершения лицом. Действие его имеет текущее значение и потому не исключает основания уголовной ответственности в прошлом»[6] .

Если понимать уголовную ответственность как правоотношение, из чего и исходит учёный, данные рассуждения можно отчасти признать обоснованными, хотя согласиться с ними полностью тоже нельзя, потому что последствием декриминализации автор не признаёт не только исключение, но даже и прекращение уголовной ответственности, предлагая в этой ситуации использовать ст. 801 УК РФ.

В то же время, на сегодняшний день более обоснованным представляется понимание уголовной ответственности как осуждения (порицания) лица и последующего претерпевания им неблагоприятных для себя последствий совершённого преступления[7]. Если принять в качестве отправной точки такую трактовку, то в период времени после совершения преступления до вступления в силу приговора суда уголовную ответственность следует признать ещё не возникшей. Именно поэтому декриминализация деяния в этом случае нивелирует её основание и не позволяет ей наступить.

Иначе обстоит дело в ситуации, когда лицо уже осуждено и отбывает наказание, а равно когда лицо отбыло наказание, но имеет судимость. Уголовная ответственность уже начала реализовываться, поэтому исключить её нельзя; возможно лишь её прекращение.

Интересен и ещё один аспект проблемы. А.П. Фильченко обосновывает невозможность отнесения декриминализации деяния к обстоятельствам, исключающим уголовную ответственность, тем соображением, что ст. 133 УПК, закрепляющая основания возникновения права на реабилитацию, не распространяет своё действие на случаи принятия закона, устраняющего преступность и наказуемость деяния[8] . Однако этот тезис не соответствует действительности, поскольку данная норма говорит о праве на реабилитацию лица, дело в отношении которого было прекращено за отсутствием состава преступления, т.е. по п. 2 ч. 1 ст. 24 УПК. Согласно же ч. 2 ст. 24 УПК к этому основанию приравнивается устранение преступности и наказуемости деяния новым уголовным законом.

Таким образом, уголовно-процессуальный закон не делает различий между отсутствием состава преступления как таковым и отсутствием состава преступления в связи с декриминализацией деяния, причём ни с точки зрения оснований прекращения уголовного дела или уголовного преследования, ни с точки зрения возникновения права на реабилитацию. 
Логика в таком подходе, безусловно, усматривается: если общество в лице государства посчитало, что деяние больше не должно быть уголовно наказуемым, оно не просто не привлекает к ответственности за него лиц, которые допустят подобное поведение в будущем. Речь идёт ещё и о том, что лица, уже вовлечённые в орбиту уголовной юстиции в связи с совершением данного деяния, должны быть свободны от всяких претензий со стороны государства, что, безусловно, зависит от стадии, на которой их «застигло» изменение уголовного закона. В случаях, когда уголовная ответственность уже начала реализовываться, можно говорить только об освобождении от наказания либо о досрочном снятии судимости, если таковое уже полностью отбыто. Однако в случаях, когда приговор суда ещё не вынесен, речь должна идти об исключении уголовной ответственности, поскольку в этой ситуации отсутствует состав преступления, а также противоправность и наказуемость деяния.

В этой связи Г.А. Есаков также отметил, что «при таком подходе, используя reduction ad absurdum [9] , отсутствие уголовного закона, криминализирующего деяние, также выступает в роли обстоятельства, исключающего уголовную ответственность» [10] . Учёный, таким образом, показывает, что отсутствие уголовного закона, устанавливающего ответственность за то или иное поведение, не является, по его мнению, обстоятельством, исключающим уголовную ответственность. Однако очевидно, что это именно так: при совершении лицом любого деяния, не нашедшего закрепления в УК РФ, правомерного или даже противоправного (например, административного правонарушения), лицо уголовной ответственности не подлежит - его уголовная ответственность невозможна, т.е. исключается.
Не стоит недооценивать этот тезис. Например, полвека назад Я.М. Брайнин полагал, что все граждане, не совершавшие преступлений, освобождаются от уголовной ответственности[11] , что сегодня признаётся ошибочным и отвергается. Поэтому следует говорить о том, что уголовная ответственность лица, не совершившего преступлений, именно исключается.

Сказанное представляется не только верным с точки зрения формальной логики, но и обоснованным в свете современных представлений об уголовном законе. Важной гарантией прав человека выступает отсутствие в уголовном праве аналогии (ч. 2 ст. 3 УК РФ), что означает невозможность привлечения лица к уголовной ответственности в том случае, если в его деянии не содержится всех признаков, предусмотренных в уголовноправовой норме. Поэтому и отсутствие уголовного закона как таковое, и его устранение в результате декриминализации деяния следует признавать обстоятельством, исключающим уголовную ответственность. В известном смысле можно даже сказать, что отсутствие уголовно-правового запрета - это главное и первое из всех возможных обстоятельств такого рода.

Таким образом, можно сформулировать следующий вывод. Декриминализация деяния должна рассматриваться как обстоятельство, исключающее уголовную ответственность. В содеянном одновременно отсутствуют состав преступления, а также такие признаки преступления, как противоправность и наказуемость. Представляется, что сегодня для признания декриминализации деяния обстоятельством, исключающим уголовную ответственность, есть и теоретические, и материальноправовые, и процессуально-правовые основания. Аналогично следует подходить к определению правовой природы отсутствия уголовного закона.

\section{Библиография:}

1. Курс уголовного права. Общая часть. В 2-х т. Т. 1. Под ред. Н.Ф. Кузнецовой, И.М. Тяжковой. М., 1999. С. 106-107; Российское уголовное право. Общая часть. Под ред. В.Н. Кудрявцева, А.В. Наумова. М., 2000. 64; Уголовное право России. Общая часть. Под ред. А.И. Рарога. М., 2007. С. 35; Уголовное право России. Части Общая и Особенная. Под ред. А.И. Рарога. M., 2012. C. 22-23.

2. Фильченко А.П. Возникновение, смягчение и прекращение уголовной ответственности (проблемы отраслевого и межотраслевого согласования). М., 2014. С. 236-237. в абстракции, в отвлечении, абстрактно, отвлечённо (лат.).

3. Есаков Г.А. Негативные признаки состава преступления: постановка вопроса // Уголовное право: стратегия развития в XXI веке. Материалы XI Международной научно-практической конференции (30-31 января 2014 г.). М., 2014. С. 104. 
4. Фильченко А.П. Возникновение, смягчение и прекращение уголовной ответственности (проблемы отраслевого и межотраслевого согласования). М., 2014. С. 237.

5. Лесниченко И.П. Уголовная ответственность: понятие и проблемы реализации. Автореф. дисс. ... канд. юрид. наук. Ростов н/Д, 2005. С. 16.

6. Фильченко А.П. Возникновение, смягчение и прекращение уголовной ответственности (проблемы отраслевого и межотраслевого согласования). М., 2014. С. 237. доведение до абсурда (лат.).

7. Есаков Г.А. Негативные признаки состава преступления: постановка вопроса // Уголовное право: стратегия развития в XXI веке. Материалы XI Международной научно-практической конференции (30-31 января 2014 г.). М., 2014. С. 104 (сноска).

8. Брайнин Я.М. Уголовная ответственность и её основание в советском уголовном праве. М., 1963. C. 247-249.

\section{References (transliterated):}

1. Kurs ugolovnogo prava. Obshchaya chast'. V 2-kh t. T. 1. Pod red. N.F. Kuznetsovoi, I.M. Tyazhkovoi. M., 1999. S. 106-107; Rossiiskoe ugolovnoe pravo. Obshchaya chast'. Pod red. V.N. Kudryavtseva, A.V. Naumova. M., 2000. 64; Ugolovnoe pravo Rossii. Obshchaya chast'. Pod red. A.I. Raroga. M., 2007. S. 35; Ugolovnoe pravo Rossii. Chasti Obshchaya i Osobennaya. Pod red. A.I. Raroga. M., 2012. S. 22-23.

2. Fil'chenko A.P. Vozniknovenie, smyagchenie i prekrashchenie ugolovnoi otvetstvennosti (problemy otraslevogo i mezhotraslevogo soglasovaniya). M., 2014. S. 236-237. v abstraktsii, v otvlechenii, abstraktno, otvlechenno (lat.).

3. Esakov G.A. Negativnye priznaki sostava prestupleniya: postanovka voprosa // Ugolovnoe pravo: strategiya razvitiya v XXI veke. Materialy XI Mezhdunarodnoi nauchno-prakticheskoi konferentsii (30-31 yanvarya 2014 g.). M., 2014. S. 104.

4. Fil'chenko A.P. Vozniknovenie, smyagchenie i prekrashchenie ugolovnoi otvetstvennosti (problemy otraslevogo i mezhotraslevogo soglasovaniya). M., 2014. S. 237.

5. Lesnichenko I.P. Ugolovnaya otvetstvennost': ponyatie i problemy realizatsii. Avtoref. diss. ... kand. yurid. nauk. Rostov n/D, 2005. S. 16.

6. Fil'chenko A.P. Vozniknovenie, smyagchenie i prekrashchenie ugolovnoi otvetstvennosti (problemy otraslevogo i mezhotraslevogo soglasovaniya). M., 2014. S. 237. dovedenie do absurda (lat.).

7. Esakov G.A. Negativnye priznaki sostava prestupleniya: postanovka voprosa // Ugolovnoe pravo: strategiya razvitiya v XXI veke. Materialy XI Mezhdunarodnoi nauchno-prakticheskoi konferentsii (30-31 yanvarya 2014 g.). M., 2014. S. 104 (snoska).

8. Brainin Ya.M. Ugolovnaya otvetstvennost' i ee osnovanie v sovetskom ugolovnom prave. M., 1963. S. 247-249. 